children's attitudes toward physical activity within the school environment. ${ }^{26}$

Supported by the Danish Health Insurance Foundation, the Danish Health Services Development Foundation, the Danish Heart Foundation, the Health Insurance Foundation of Denmark, the Danish Medical Research Council, the Funen Prevention Council, the Danish Sports Research Council, and the Rosalie Petersen Foundation.

1 WHO Scientific Group. Primary prevention of essential hypertension. WHO Tech Rep Ser 1983;686:1-40.

2 The 1988 report of the Joint National Committee on Detection, Evaluation, and Treatment of High Blood Pressure. Arch Intern Med 1988;148:1023-38.

Nelson L, Jennings GL, Esler MD, Korner PI. Effect of changing levels of physical activity on blood pressure and haemodynamics in essential physical activity on blood pressure

4 Jennings G, Nelson L, Nestel P, Esler M, Korner P, Burton D, et al. The effects of changes in physical activity on major cardiovascular risk factors, hemodynamics, sympathetic function, and glucose utilization in man: a controlled study of four levels of activity. Circulation 1986;73:30-40.

5 Seals DR, Hagberg JM. The effect of exercise training on human hypertension a review. Med Sci Sports Exerc 1984;16:207-15.

6 Subcommittee on Nonpharmacological Therapy. Nonpharmacological Subcommittee on Nonpharmacological Therapy. Nonpharmacological
approaches to the control of high blood pressure. Hypertension 1986;8: 414-67.

7 Report of the Second Task Force on Blood Pressure Control in Children1987. Pediatrics $1987 ; 79: 1-25$

8 Fagard R. Habitual physical activity, training, and blood pressure in normoand hypertension. Int F Sports Med 1985;6:57-67.

9 Montoye HJ. Physical activity, physical fitness, and heart disease risk factors in children. In: Stull GA, Eckert HM, eds. Effects of physical activity on children. Champaign, Illinois: Human Kinetics Publishers, 1986:127-52. American Academy of Physical Education Papers, No 19.

10 Vaccaro P, Mahon AD. The effects of exercise on coronary heart disease risk factors in children. Sports Med 1989;8:139-53.

11 Hansen HS, Hyldebrandt N, Nielsen JR, Froberg K. Blood pressure distribution in a school-age population aged 8-10 years-the Odense schoolchild study. f Hypertens 1990;8:641-6.
12 Tanner JM, ed. Growth at adolescence. Oxford: Blackwell Scientific Publicaions, 1962

13 Hansen HS, Froberg K, Nielsen JR, Hyldebrandt N. A new approach to assessing maximal aerobic power in children: the Odense school child study. Eur F Appl Physiol 1989;58:618-24.

14 Cole IWL, Grizzle IE. Applications of multivariate analysis of variance to repeated measures experiments. Biometrics 1966;22:810-28.

15 O'Brien RG, Kaiser MK. MANOVA method for analyzing repeated measure designs: an extensive primer. Psychol Bull 1985;97:316-33.

16 SPSS Inc. SPSSX user's guide. New York: McGraw-Hill Book Company, 1983:487-8.

17 Gunsolley JC, Chinchilli VM, Koertge TE, Palcanis KG, Sarbin AG, Brooks $\mathrm{CN}$. The use of repeated measures analysis of variance for plaque and gingival indices. F Clin Periodontol 1989;16:156-63.

18 Eriksson BO, Koch G. Effect of physical training on haemodynamic response during submaximal and maximal exercise in 11-13-year old bovs. Acta Physiol Scand 1973;87:27-39.

19 Dwyer T, Coonan WE, Leitch DR, Hetzel BS, Baghurst RA. An investigation of the effects of daily physical activity on the health of primary school

20 Linder CW, DuRant RH, Mahoney OM. The effect of physical conditioning on serum lipids and lipoproteins in white male adolescents. Med Sci Sports on serum lipids and
Exerc 1983;15:232-6.

21 Stone EJ. School-based health research funded by the National Heart, Lung, and Blood Institute. F Sch Health 1985;55:168-74.

22 Puska P, Vartiainen E, Pallonen U, Salonen JT, Pö̀hiä P, Koskela K, et al. The North Karelia Youth Project: evaluation of two years of intervention on health behavior and CVD risk factors among 13 to 15 -year-old children. Prev Med 1982;11:550-70

23 Tell GS, Vellar OD. Non-communicable disease risk factor intervention in Norwegian adolescents: the Oslo youth study. In: Hetzel BS, Berenson GS eds. Cardiovascular risk factors in childhood: epidemiology and prevention. Amsterdam: Elsevier, 1987:203-17.

24 Walter HJ, Hofman A, Vaughan AD, Wynder EL. Modification of risk factor for coronary heart disease. $N$ Engl F Med 1988;318:1093-1100.

25 Berenson GS, Shear CL, Chiang YK, Webber LS, Voors AW. Combined low dose medication and primary intervention over a 30-month period for sustained high blood pressure in childhood. Am f Med Sci 1990;299:79-86. 26 Demarco T, Sidney K. Enhancing children's participation in physical activity. I Sch Health 1989;59:337-40.

(Accepted 4 fuly 1991)
Division of Clinical

Neurosciences, Lilly Research Laboratories, Eli

Lilly and Company,

Indianapolis, Indiana

46285, USA

Charles M Beasley Jr, MD,

clinical resource physician

Bruce E Dornseif, PHD,

research scientist

Janet C Bosomworth, BS, statistician

Mary E Sayler, MS,

statistician

Alvin H Rampey Jr, PHD, senior statistician

John H Heiligenstein, MD, clinical research physician

Vicki L Thompson, MSN, clinical research administrator David J Murphy, BBA, senior information analyst

Daniel N Masica, MD,

international research adviser

Correspondence to: Dr Charles M Beasley Jr, Lilly Research Laboratories, Eli Lilly and Company, Lilly Corporate Center 2128,

Indianapolis, Indiana 46285 , USA.

BM7 1991;303:685-92

\title{
Fluoxetine and suicide: a meta-analysis of controlled trials of treatment for depression
}

Charles M Beasley Jr, Bruce E Dornseif, Janet C Bosomworth, Mary E Sayler, Alvin H Rampey Jr, John H Heiligenstein, Vicki L Thompson, David J Murphy, Daniel N Masica

\section{Abstract}

Objective-A comprehensive meta-analysis of clinical trial data was performed to assess the possible association of fluoxetine and suicidality (suicidal acts and ideation).

Design-Retrospective analysis of pooled data from 17 double blind clinical trials in patients with major depressive disorder comparing fluoxetine $(\mathbf{n}=$ $1765)$ with a tricyclic antidepressant $(n=731)$ or placebo $(n=569)$, or both.

Main outcome measures-Multiple data sources were searched to identify patients with suicidal acts. Suicidal ideation was assessed with item 3 of the Hamilton depression rating scale, which systematically rates suicidality. Emergence of substantial suicidal ideation was defined as a change in the rating of this item from 0 or 1 at baseline to 3 or 4 during double blind treatment; worsening was defined as any increase from baseline; improvemen was defined as a decrease from baseline at the last visit during the treatment.

Results - Suicidal acts did not differ significantly in comparisons of fluoxetine with placebo $(0 \cdot 2 \% v$ $0 \cdot 2 \%, p=0 \cdot 494$, Mantel-Haenszel adjusted incidence difference) and with tricyclic antidepressants $(0.7 \%$ $v 0.4 \%, \mathrm{p}=0.419)$. The pooled incidence of suicidal acts was $0.3 \%$ for fluoxetine, $0.2 \%$ for placebo, and $0.4 \%$ for tricyclic antidepressants, and fluoxetine did not differ significantly from either placebo $(p=0.533$, Pearson's $\left.\chi^{2}\right)$ or tricyclic antidepressants $(\mathbf{p}=0.789)$. Suicidal ideation emerged marginally significantly less often with fluoxetine than with placebo $(0.9 \% v$ $2 \cdot 6 \%, p=0.094)$ and numerically less often than with tricyclic antidepressants $(1.7 \% \vee 3.6 \%, p=0 \cdot 102)$.
The pooled incidence of emergence of substantial suicidal ideation was $1 \cdot 2 \%$ for fluoxetine, $2 \cdot 6 \%$ for placebo, and $3.6 \%$ for tricyclic antidepressants. The incidence was significantly lower with fluoxetine than with placebo $(p=0.042)$ and tricyclic antidepressants $(p=0.001)$. Any degree of worsening of suicidal ideation was similar with fluoxetine and placebo $(15.4 \% v 17.9 \%, p=0 \cdot 196)$ and with fluoxetine and tricyclic antidepressants $(15.6 \%$ v $16.3 \%$, $\mathbf{p}=\mathbf{0 . 7 9 3 )}$. The pooled incidence of worsening of suicidal ideation was $15 \cdot 3 \%$ for fluoxetine, $17.9 \%$ for placebo, and $16.3 \%$ for tricyclic antidepressants. The incidence did not differ significantly with fluoxetine and placebo $(p=0 \cdot 141)$ or tricyclic antidepressants $(p=0.542)$. Suicidal ideation improved significantly more with fluoxetine than with placebo $(72.0 \% v 54.8 \%, p<0.001)$ and was similar to the improvement with tricyclic antidepressants $(72.5 \% \mathrm{v}$ $69.8 \%, p=0.294)$. The pooled incidence of improvement of suicidal ideation was $\mathbf{7 2 \cdot 2} \%$ for fluoxetine, $\mathbf{5 4 . 8 \%}$ for placebo, and $\mathbf{6 9 . 8 \%}$ for tricyclic antidepressants. The incidence with fluoxetine was significantly greater than with placebo $(p<0.001)$ and did not differ from that with tricyclic antidepressants $(\mathbf{p}=\mathbf{0} \cdot 296)$.

Conclusion-Data from these trials do not show that fluoxetine is associated with an increased risk of suicidal acts or emergence of substantial suicidal thoughts among depressed patients.

\section{Introduction}

Because depression is an important risk factor for suicide $^{1-3}$ there is a need to study the effects of 
antidepressants on suicidality (suicidal acts and suicidal ideation) in patients with major depressive illnesses. Though it is generally expected that any treatment that improves the depression is also likely to reduce suicidality, one study did not support this view. ${ }^{4}$ It has not been suggested until fairly recently that, paradoxically, worsening of suicidality might in a small subset of patients be associated with the use of antidepressants. " " Five reports" 1" (one subsequently retracted") have hypothesised that the use of fluoxetine (a serotonin uptake inhibitor) might lead to the emergence or worsening of suicidal ideation in a very small proportion of patients taking this drug. Patients receiving different classes of antidepressants, including fluoxetine, have shown no differences in rates of suicidality, ${ }^{12}$ while greater improvement with respect to suicidality has occurred with serotonin uptake inhibitors than with comparative drugs in depressive illnesses. ${ }^{13-16}$ Recently Rouillon et al reported that maprotiline (a noradrenaline uptake inhibitor) was associated with a greater incidence of suicidal acts than placebo during long term treatment of depression.' To examine any possible relation of fluoxetine to the emergence of suicidality, we carried out a comprehensive meta-analysis of all relevant clinical trial data.

\section{Methods}

TYPES AND SOURCES OF DATA

The meta-analysis was carried out on the United States investigational new drug depression clinical trial database for fluoxetine; this consists of all double blind, randomised trials of fluoxetine in depression controlled against placebo or tricyclic antidepressants. Trials that had been completed and analysed up to the end of December 1989 were included. The exclusions were: depression trials that had not used a comparative drug, trials that had used a comparator other than placebo or a tricyclic antidepressant, non-blind extensions of controlled trials, non-blind compassionate trials, trials for other potential indications, and pharmacokinetic trials.

For these analyses the clinical trials were organised into five analysis groups: (1) placebo controlled trials (five trials); (2) trials controlled with tricyclic antidepressants (10 trials); (3) trials controlled with placebos and tricyclic antidepressants (two trials); (4) analysis group 1 and the fluoxetine and placebo arms of analysis group 3; and (5) analysis group 2 and the fluoxetine and tricyclic antidepressant arms of analysis group 3. The specific protocols included in each analysis group and the characteristics of the patients studied are summarised in the Appendix.

Potential cases of suicidal acts were first identified electronically by searching two sources: (a) clinical report form data from the trials (for adverse events, reasons for trial discontinuation, Hamilton depression rating scale item 3 scores, ${ }^{18}$ and free text comments) and (b) data from the drug experience network for adverse events and outcomes. The drug experience network database contains reports of all serious adverse events (as defined by United States Food and Drug Administration criteria) that have occurred in clinical trials, as well as all adverse events voluntarily reported as part of the manufacturer's (Eli Lilly and Company) post-marketing surveillance. ${ }^{19}$ Those clinical comments that had not been transferred to computer were examined by the research staff, and all cases in which it was clear that there had been no suicidal act were eliminated. All remaining cases were then reviewed independently by two Eli Lilly and Company psychiatrists, who were blind to the drug that had been used, to determine whether or not a suicidal act had occurred.

\section{DEFINITIONS}

A suicidal act was defined as any behaviour undertaken purposefully from which the outcome was likely to be self harm, and where no explicit data suggested that suicide had not been intended. ${ }^{3}$ Actions that might be described as suicidal gestures were not excluded. A suicidal act had to have occurred before or during the day following the last day of double blind treatment, in compliance with the trial protocol. This time limit was adopted for three reasons: post-discontinuation data had not been collected as part of the trials; the end of participation in the trial or withdrawal of the study treatment, or both, might have influenced an event occurring after discontinuation; and other drugs might have been started after the end of the study treatment.

Suicidal ideation was identified by the scores on item 3 of the Hamilton depression rating scale. The scale defines these as: $0=$ absence of such ideation; $1=$ doubtful or trivial ideation; $2=$ mild ideation; $3=$ active suicidal ideation and suggestive behaviours; and $4=$ severe ideation, usually involving a suicidal act.

Emergence of substantial suicidal ideation was defined as a change in score on item 3 of the Hamilton depression rating scale from 0 or 1 at baseline to 3 or 4 at any time during the double blind treatment. Emergence of substantial suicidal ideation was evaluated only for those patients whose score was 0 or 1 at baseline.

Worsening of suicidal ideation was defined as any increase in item 3 score from baseline at any time during double blind treatment. Worsening was evaluated only for those patients who could worsen during double blind treatment -that is, those whose score was less than 4 at baseline.

Improvement of suicidal ideation was defined as any decrease in item 3 score from baseline to the last evaluation while the patient was in double blind treatment. Improvement was evaluated only for those patients who could improve during double blind treatment -that is, those whose score was greater than 0 at baseline.

DESIGN

Data were analysed from 17 single centre and multicentre randomised, double blind trials including 3065 patients $(1765$ receiving fluoxetine, 731 receiving tricyclic antidepressants (amitriptyline, desipramine, doxepin, imipramine, nortriptyline), and 569 receiving placebo). Five trials compared fluoxetine with placebo, 10 compared fluoxetine with a tricyclic antidepressant, and two compared fluoxetine with a tricyclic antidepressant and a placebo.

Fluoxetine doses ranged from $20 \mathrm{mg}$ to $80 \mathrm{mg}$ a day (except in one trial where the range was $5 \mathrm{mg}$ to $40 \mathrm{mg}$ a day); in 15 trials the fluoxetine doses were individually adjusted, and in two the patients were randomly assigned to one of several fixed doses. Doses of tricyclic antidepressants were adjusted individually within current manufacturers' guidelines.

In 16 trials the patients met criteria for nonpsychotic major depressive disorder (three trials used Research Diagnostic Criteria, ${ }^{20}$ nine trials used the Diagnostic and Statistical Manual of Mental Disorders, 3rd edition (DSM-III) criteria for symptoms of one month's duration, and four trials required DSM-III criteria $\left.^{21}\right)$. Most patients had a score $\geqslant 20$ on the 21 item Hamilton depression rating scale (one trial used a score $\geqslant 18$ and one trial included a stratum of patients with scores between 14 and 19), and most did not improve their score by $20 \%$ or more during the lead in period (approximately one week of single blind placebo treatment). In one trial the patients were diagnosed by DSM-III criteria as having bipolar disorder and being depressed; they had a baseline score $\geqslant 20$ on the 21 item Hamilton depression rating scale and failed to 
show a $20 \%$ or greater improvement in this score during placebo lead in.

Written informed consent was given appropriately in all cases.

Exclusion criteria included a history of substance misuse within one year; psychotic or organic mental disorder; serious suicidal risk as clinically assessed by the investigator (suicidal ideation was not a criterion; two inpatient trials did not have an explicit exclusion criterion based on serious suicidal risk); and unstable medical conditions or any medical condition precluding use of one of the drugs used in these studies.

Trials lasted five or six weeks with evaluations about once a week, except in one inpatient trial where there were two evaluations a week for the first two weeks of double blind treatment and one outpatient trial where there were two evaluations during the first week and three during the second week of double blind treatment.

\section{ANALYTICAL AND STATISTICAL METHODS}

Descriptive statistics, including the incidence of suicidal acts and the emergence of substantial suicidal ideation (the primary measures) and worsening of suicidal ideation and improvement of suicidal ideation, were computed for all individual trials, for analysis groups 4 and 5 , and for all trials combined. Inferential statistical analyses were performed for analysis group 4 (fluoxetine $v$ placebo), analysis group 5 (fluoxetine $v$ tricyclic antidepressants), and all trials combined. All 3065 randomised patients were included in the analysis of suicidal acts. A total of 1999 patients with a baseline score on item 3 of the Hamilton depression rating scale of 0 or 1 and at least one post-baseline score were included in the analysis of emergence of substantial suicidal ideation. The incidence of worsening of suicidal ideation was based on 2995 patients with a baseline score $<4$ and at least one post-baseline score. The incidence of improvement of suicidal ideation was based on 2053 patients with a baseline score $>0$ and at least one post-baseline score.

The incidence difference and corresponding 95\% confidence interval was used to compare the incidence of the four outcome variables (suicidal acts, emergence of substantial suicidal ideation, worsening of suicidal ideation, improvement of suicidal ideation) between treatments for individual clinical trials. The incidence difference ${ }^{22}$ was defined as the incidence in patients treated with fluoxetine minus the incidence in patients treated with the comparator. An incidence difference greater than 0 implies a numerically higher incidence with fluoxetine than with the comparator; an incidence difference less than 0 implies a numerically higher incidence with the comparator than with fluoxetine; and an incidence difference equal to 0 implies equal incidence.

Owing to potential heterogeneity of trials the adjusted incidence difference, which stratifies by trial, was used to compare the incidence of the four outcome variables between treatments in analysis groups 4 and 5 . The individual incidence differences

TABLE I - Characteristics of patients at baseline

\begin{tabular}{|c|c|c|c|c|c|}
\hline & \multirow[b]{2}{*}{ No of patients } & \multirow{2}{*}{$\operatorname{Men}($ women $)$} & \multirow{2}{*}{$\begin{array}{l}\text { Median range) } \\
\text { (years) }\end{array}$} & \multicolumn{2}{|c|}{$\begin{array}{c}\text { Mean (SI) ) score on Hamilton } \\
\text { depression rating scale }\end{array}$} \\
\hline & & & & 21 Items & Item 3 \\
\hline \multicolumn{6}{|c|}{ Analysis group 4: } \\
\hline Fluoxetine & 1322 & $39(61)$ & $38(13-70)$ & $23 \cdot 5(5 \cdot 3)$ & $0.9(0.9)$ \\
\hline Placebo & 569 & $4159)$ & $37(12-70)$ & $25 \cdot 5(5 \cdot 5)$ & $1 \cdot 1(0.9)$ \\
\hline \multicolumn{6}{|c|}{ Analysis group 5: } \\
\hline Fluoxetine & 720 & $34(66)$ & $43(19-90)$ & $27 \cdot 2(5 \cdot 4)$ & $1 \cdot 3(1 \cdot 0)$ \\
\hline Tricyclics & 731 & $36(64)$ & $45(18-88)$ & $27 \cdot 2(5 \cdot 5)$ & $1 \cdot 4(1 \cdot 0)$ \\
\hline \multicolumn{6}{|l|}{ All trials: } \\
\hline Fluoxetine & 1765 & $38(62)$ & $40(13-90)$ & $24 \cdot 4(5 \cdot 6)$ & $1 \cdot 0(1 \cdot 0)$ \\
\hline Tricyclics & 731 & $36(64)$ & $45(18-88)$ & $27 \cdot 2(5 \cdot 5)$ & $1 \cdot 4(1.0)$ \\
\hline Placebo & 569 & $41(59)$ & $37(12-70)$ & $25 \cdot 5(5 \cdot 5)$ & $1 \cdot 1(0.9)$ \\
\hline
\end{tabular}

were combined across the clinical trials to form the adjusted incidence difference (also referred to as the adjusted risk difference) by using the binomial, unconditional Mantel-Haenszel estimate (Equation 12). ${ }^{23}$ This estimate is an average of the incidence differences of the individual trials weighted by sample size. The variance of the Mantel-Haenszel risk difference (Equation 14) (3) $^{23}$ wased to form the $95 \%$ confidence intervals (Equation 19) ) $^{24}$ for the adjusted incidence differences and the associated $\mathrm{p}$ values (Equation 6.37).

When interpreting the adjusted incidence difference we considered the consistency (homogeneity) of the treatment comparisons across trials. To test for lack of homogeneity of treatment comparisons across trials we used the Breslow-Day test. ${ }^{26} 27$ Although the BreslowDay test is designed to test for homogeneity of odds ratios across trials, it was used here to test for a lack of homogeneity of treatment comparisons across trials in general. Results of the Breslow-Day test were not significant in any analysis; however, it is still useful to consider treatment comparisons by individual trial. Figures 1-4 (given below) show the incidence differences and $95 \%$ confidence intervals for individual trials as well as the adjusted incidence differences and the $95 \%$ confidence intervals for analysis groups 4 and 5 for the four outcome variables and allow visual inspection of the treatment comparisons.

In addition to heterogeneity of trials, it was important to consider potential differences in baseline distributions of scores on item 3 of the Hamilton depression rating scale across treatments within trials when comparing worsening and improvement of suicidal ideation. Therefore we performed a test of potential differences in these distributions for treatments in analysis groups 4 and 5 . Estimators and test statistics used for these comparisons would have been appropriately adjusted for such differences, but none were found.

The Mantel-Haenszel adjusted incidence difference and its associated $p$ value for analysis groups 4 and 5 constitute the primary inferential analytical method for the four outcome variables. This method adjusts for potential heterogeneity across trials and constitutes the basis for all conclusions discussed. In addition, Pearson's $\chi^{2}$ tests were used for pairwise comparisons of treatment, combining the data across all 17 trials. This analysis is provided because clinical criteria and trial methods were relatively similar across the 17 trials; it constitutes a secondary inferential analysis for the four outcome variables.

Baseline suicidality was measured by the percentage of patients with passive or active suicidal thinking (score on item 3 of the Hamilton depression rating scale $\geqslant 2$ ) in all patients. Baseline suicidality was measured for all randomised patients with baseline data (2999 of 3065) who had at least one post-baseline measurement.

For all analyses except for the Breslow-Day test statistical significance was defined as $p<0 \cdot 05$. For the Breslow-Day test $\mathrm{p}<0 \cdot 1$ was considered significant.

The FREQ procedure in SAS 5.18 $18^{27}$ was used for the Breslow-Day test and Pearson's $\chi^{2}$ test. The incidence difference for individual trials and the adjusted incidence differences for groups of trials were calculated in an SAS data step.

\section{Results}

PATIENTS' CHARACTERISTICS AT BASELINE

Table I lists the baseline characteristics of the patients included in these analyses for analysis groups 4 and 5 as well as the total combined population organised by type of treatment. 
SUICIDAL ACTS AND IDEATION

Table II provides a summary of the incidence of the four outcome variables for each individual trial, for the pooled analysis groups 4 and 5, and for the total combined pool of patients organised by treatment. It can be consulted when examining the results of the inferential analyses described below.

\section{SUICIDAL ACTS}

During the single blind placebo lead in period of these trials, three suicidal acts (one fatal) were identified. One of these patients was continued in the trial, randomised to fluoxetine, and completed double blind treatment without any further suicidal act.

Figure I presents the incidence differences for the individual trials and the adjusted incidence differences with $95 \%$ confidence intervals and $p$ values for pooled analysis groups 4 and 5 . The adjusted incidence difference for fluoxetine compared with placebo was $0.2(-0.3$ to $0.7, p=0.494)$; for fluoxetine compared with tricyclic antidepressants it was $0.3(-0.4$ to $1 \cdot 1$, $\mathrm{p}=0.419$ ); neither difference approached significance.

The pooled incidence of suicidal acts was $0 \cdot 3 \%$ for fluoxetine, $0 \cdot 2 \%$ for placebo, and $0 \cdot 4 \%$ for tricyclic antidepressants. Pearson's $\chi^{2}$ test showed no significant difference for either fluoxetine versus placebo $(\mathrm{p}=$ 0.533 ) or fluoxetine versus tricyclic antidepressants $(\mathrm{p}=0 \cdot 789)$.

\section{SUICIDAL IDEATION AT BASELINE}

Serious suicidal risk, as clinically assessed by the investigator, was an exclusion criterion (except in two trials), but suicidal ideation was not. Analysis of scores for item 3 on the Hamilton depression rating scale, available for 2999 patients, indicated that 1000 (33\%) had suicidal ideation at baseline to the extent that the score was $\geqslant 2$.

EMERGENCE OF SUBSTANTIAL SUICIDAL IDEATION

Figure 2 presents the data for emergence of substantial suicidal ideation. Emergence of substantial suicidal ideation occurred marginally significantly less often with fluoxetine than with placebo $(-1 \cdot 5(-3 \cdot 3$ to $0 \cdot 3)$, $\mathrm{p}=0.094)$ and numerically less often with fluoxetine than with tricyclic antidepressants $(-1 \cdot 8(-4 \cdot 0$ to $0 \cdot 4)$, $\mathrm{p}=0 \cdot 102)$.

TABLE II - Incidence of suicidal acts, emergence of substantial suicidal ideation, worsening of suicidal ideation, and improvement of suicidal ideation in patients with major depressive disorder in 17 double blind clinical trials ${ }^{\star}$

\begin{tabular}{|c|c|c|c|c|c|c|c|c|c|}
\hline \multirow[b]{2}{*}{ Trial } & \multirow[b]{2}{*}{ Treatment } & \multicolumn{2}{|c|}{ Suicidal acts } & \multicolumn{2}{|c|}{$\begin{array}{l}\text { Emergence of substantial } \\
\text { suicidal ideation }\end{array}$} & \multicolumn{2}{|c|}{$\begin{array}{l}\text { Worsening of suicidal } \\
\text { ideation }\end{array}$} & \multicolumn{2}{|c|}{$\begin{array}{l}\text { Improvement of suicidal } \\
\text { ideation }\end{array}$} \\
\hline & & $\begin{array}{c}\text { No of } \\
\text { patients }\end{array}$ & No $(\%)$ & $\begin{array}{c}\text { No of } \\
\text { patients }\end{array}$ & No $(\%)$ & $\begin{array}{c}\text { No of } \\
\text { patients }\end{array}$ & No $(\%)$ & $\begin{array}{c}\text { No of } \\
\text { patients }\end{array}$ & $\mathrm{No}(\%)$ \\
\hline \multicolumn{10}{|l|}{ Analysis group 1: } \\
\hline \multirow{2}{*}{ Trial 1} & Fluoxetine & 55 & & 39 & & 55 & $3(5 \cdot 5)$ & 32 & $25(78 \cdot 1)$ \\
\hline & Placebo & 56 & & 41 & $1(2 \cdot 4)$ & 56 & $8(14 \cdot 3)$ & 37 & $23(62 \cdot 2)$ \\
\hline \multirow[t]{2}{*}{ Trial 2} & Fluoxetine & 45 & & 39 & & 45 & $8(17 \cdot 8)$ & 34 & $27(79 \cdot 4)$ \\
\hline & Placebo & 45 & & 37 & & 42 & $5(11.9)$ & 36 & $21(58 \cdot 3)$ \\
\hline \multirow[t]{2}{*}{ Trial 3} & Fluoxetine & 21 & & 9 & $1(11 \cdot 1)$ & 21 & $4(19 \cdot 0)$ & 17 & $16(94 \cdot 1)$ \\
\hline & Placebo & 19 & $1(5 \cdot 3)$ & 8 & & 19 & $4(21 \cdot 1)$ & 15 & $12(80 \cdot 0)$ \\
\hline \multirow[t]{2}{*}{ Trial 4} & Fluoxetine & 639 & $1(0 \cdot 2)$ & 493 & $4(0 \cdot 8)$ & 611 & $100(16 \cdot 4)$ & 309 & $206(66 \cdot 7)$ \\
\hline & Placebo & 107 & & 87 & $3(3 \cdot 4)$ & 104 & $20(19 \cdot 2)$ & 48 & $26(54 \cdot 2)$ \\
\hline \multirow[t]{2}{*}{ Trial 5} & Fluoxetine & 285 & & 210 & $2(1 \cdot 0)$ & 277 & $37(13 \cdot 4)$ & 171 & $131(76 \cdot 6)$ \\
\hline & Placebo & 78 & & 53 & & 77 & $12(15 \cdot 6)$ & 52 & $30(57 \cdot 7)$ \\
\hline \multirow{3}{*}{$\begin{array}{l}\text { Analysis group 2: } \\
\quad \text { Trial } 6\end{array}$} & & & & & & & & & \\
\hline & Fluoxetine & 26 & & 9 & & 26 & & 26 & $23(88 \cdot 5)$ \\
\hline & $\begin{array}{l}\text { Tricyclic } \\
\text { antidepressant }\end{array}$ & 24 & & 8 & & 24 & $1(4 \cdot 2)$ & 24 & $21(87 \cdot 5)$ \\
\hline \multirow[t]{2}{*}{ Trial 7} & Fluoxetine & 56 & $2(3 \cdot 6)$ & 31 & $2(6 \cdot 5)$ & 55 & $17(30 \cdot 9)$ & 40 & $28(70 \cdot 0)$ \\
\hline & $\begin{array}{l}\text { Tricyclic } \\
\text { antidepressant }\end{array}$ & 62 & & 33 & $3(9 \cdot 1)$ & 62 & $15(24 \cdot 2)$ & 49 & $36(73 \cdot 5)$ \\
\hline \multirow[t]{2}{*}{ Trial 8} & Fluoxetine & 55 & & 26 & & 55 & $5(9 \cdot 1)$ & 47 & $36(76 \cdot 6)$ \\
\hline & $\begin{array}{l}\text { Tricyclic } \\
\text { antidepressant }\end{array}$ & 54 & & 28 & & 54 & $2(3 \cdot 7)$ & 49 & $37(75 \cdot 5)$ \\
\hline \multirow[t]{2}{*}{ Trial 9} & Fluoxetine & 79 & & 60 & $2(3 \cdot 3)$ & 77 & $13(16 \cdot 9)$ & 50 & $35(70 \cdot 0)$ \\
\hline & $\begin{array}{l}\text { Tricyclic } \\
\text { antidepressant }\end{array}$ & 80 & & 57 & & 76 & $8(10 \cdot 5)$ & 48 & $32(66 \cdot 7)$ \\
\hline \multirow[t]{2}{*}{ Trial 10} & Fluoxetine & 65 & & 39 & & 62 & $9(14 \cdot 5)$ & 36 & $31(86 \cdot 1)$ \\
\hline & $\begin{array}{l}\text { Tricyclic } \\
\text { antidepressant }\end{array}$ & 65 & & 38 & $1(2 \cdot 6)$ & 64 & $11(17 \cdot 2)$ & 45 & $31(68 \cdot 9)$ \\
\hline \multirow[t]{2}{*}{ Trial 11} & Fluoxetine & 32 & & 19 & · & 30 & $1(3 \cdot 3)$ & 20 & $8(40 \cdot 0)$ \\
\hline & $\begin{array}{l}\text { Tricyclic } \\
\text { antidepressant }\end{array}$ & 32 & & 24 & & 32 & $4(12 \cdot 5)$ & 23 & $11(47 \cdot 8)$ \\
\hline \multirow[t]{2}{*}{ Trial 12} & Fluoxetine & 65 & $1(1 \cdot 5)$ & 37 & & 65 & $9(13.8)$ & 57 & $43(75 \cdot 4)$ \\
\hline & $\begin{array}{l}\text { Tricyclic } \\
\text { antidepressant }\end{array}$ & 71 & $2(2 \cdot 8)$ & 35 & $4(11 \cdot 4)$ & 71 & $16(22 \cdot 5)$ & 63 & $45(71 \cdot 4)$ \\
\hline \multirow[t]{2}{*}{ Trial 13} & Fluoxetine & 31 & & 15 & & 30 & $5(16 \cdot 7)$ & 22 & $12(54 \cdot 5)$ \\
\hline & $\begin{array}{l}\text { Tricyclic } \\
\text { antidepressant }\end{array}$ & 30 & & 16 & & 30 & $4(13 \cdot 3)$ & 21 & $8(38 \cdot 1)$ \\
\hline Trial 14 & Fluoxetine & 28 & & 10 & $1(10 \cdot 0)$ & 28 & $3(10 \cdot 7)$ & 21 & $16(76 \cdot 2)$ \\
\hline & $\begin{array}{l}\text { Tricyclic } \\
\text { antidepressant }\end{array}$ & 30 & $1(3 \cdot 3)$ & 23 & $1(4 \cdot 3)$ & 30 & $9(30 \cdot 0)$ & 15 & $11(73 \cdot 3)$ \\
\hline Trial 15 & Fluoxetine & 6 & & 3 & & 5 & $2(40 \cdot 0)$ & 3 & $2(66 \cdot 7)$ \\
\hline & $\begin{array}{l}\text { Tricyclic } \\
\text { antidepressant }\end{array}$ & 7 & & 3 & & 6 & $1(16 \cdot 7)$ & 5 & $5(100 \cdot 0)$ \\
\hline Analysis group 3: & & & & & & & & & \\
\hline Trial 16 & Fluoxetine & 247 & $2(0 \cdot 8)$ & 140 & $2(1 \cdot 4)$ & 244 & $43(17 \cdot 6)$ & 189 & $137(72 \cdot 5)$ \\
\hline & Placebo & 235 & & 137 & $6(4 \cdot 4)$ & 232 & $45(19 \cdot 4)$ & 183 & $97(53 \cdot 0)$ \\
\hline & $\begin{array}{l}\text { Tricyclic } \\
\text { antidepressant }\end{array}$ & 246 & & 130 & $6(4 \cdot 6)$ & 241 & $38(15 \cdot 8)$ & 195 & $141(72 \cdot 3)$ \\
\hline Trial 17 & Fluoxetine & 30 & & 22 & & 30 & $3(10 \cdot 0)$ & 24 & $17(70 \cdot 8)$ \\
\hline & Placebo & 29 & & 17 & & 29 & $6(20 \cdot 7)$ & 25 & $8(32 \cdot 0)$ \\
\hline & $\begin{array}{l}\text { Tricyclic } \\
\text { antidepressant }\end{array}$ & 30 & & 23 & & 30 & $8(26 \cdot 7)$ & 22 & $12(54 \cdot 5)$ \\
\hline Analysis group $4 \dagger$ & Fluoxetine ${ }^{\star}$ & 1322 & $3(0 \cdot 2)$ & 952 & $9(0 \cdot 9)$ & 1283 & $198(15 \cdot 4)$ & 776 & $559(72 \cdot 0)$ \\
\hline & Placebo & 569 & $1(0 \cdot 2)$ & 380 & $10(2 \cdot 6)$ & 559 & $100(17.9)$ & 396 & $217(54 \cdot 8)$ \\
\hline Analysis group $5 \dagger$ & Fluoxetine ${ }^{\star}$ & 720 & $5(0 \cdot 7)$ & 411 & $7(1 \cdot 7)$ & 707 & $110(15 \cdot 6)$ & 535 & $388(72 \cdot 5)$ \\
\hline & $\begin{array}{l}\text { Tricyclic } \\
\text { antidepressant }\end{array}$ & 731 & $3(0 \cdot 4)$ & 418 & $15(3 \cdot 6)$ & 720 & $117(16 \cdot 3)$ & 559 & $390(69 \cdot 8)$ \\
\hline All trials combined & Fluoxetine & 1765 & $6(0 \cdot 3)$ & 1201 & $14(1 \cdot 2)$ & 1716 & $262(15 \cdot 3)$ & 1098 & $793(72 \cdot 2)$ \\
\hline & Placebo & 569 & $1(0 \cdot 2)$ & 380 & $10(2 \cdot 6)$ & 559 & $100(17 \cdot 9)$ & 396 & $217(54 \cdot 8)$ \\
\hline & $\begin{array}{l}\text { Tricyclic } \\
\text { antidepressant }\end{array}$ & 731 & $3(0 \cdot 4)$ & 418 & $15(3 \cdot 6)$ & 720 & $117(16 \cdot 3)$ & 559 & $390(69 \cdot 8)$ \\
\hline
\end{tabular}


The pooled incidence of emergence of substantial suicidal ideation was $1 \cdot 2 \%$ for fluoxetine, $2 \cdot 6 \%$ for placebo, and $3.6 \%$ for tricyclic antidepressants. Pearson's $\gamma^{2}$ test showed a lower incidence with fluoxetine than with placebo $(\mathrm{p}=0.042)$ or tricyclic antidepressants $(\mathrm{p}=0 \cdot 001)$.

\section{WORSENING OF SUICIDAL IDEATION}

Figure 3 presents the data for worsening of suicidal ideation. For both comparisons worsening of suicidal ideation was similar with fluoxetine and with placebo or tricyclic antidepressants (fluoxetine versus placebo $-2.6(-6.6$ to 1.3$) \mathrm{p}=0.196$; fluoxetine versus tricyclic antidepressants $-0 \cdot 5(-4 \cdot 2$ to $3 \cdot 2) p=0 \cdot 793)$.

The pooled incidence of worsening of suicidal ideation was $15 \cdot 3 \%$ for fluoxetine, $17 \cdot 9 \%$ for placebo, and $16.3 \%$ for tricyclic antidepressants. Pearson's $\chi^{2}$ test showed no significant difference for either fluoxetine versus placebo $(p=0 \cdot 141)$ or fluoxetine versus tricyclic antidepressants $(p=0 \cdot 542)$.

\section{IMPROVEMENT OF SUICIDAL IDEATION}

Figure 4 presents the data for improvement of suicidal ideation. There was significantly more improvement with fluoxetine than with placebo $(18 \cdot 8$ $(12 \cdot 7$ to $24 \cdot 9), \mathrm{p}<0 \cdot 001)$. Improvement was similar
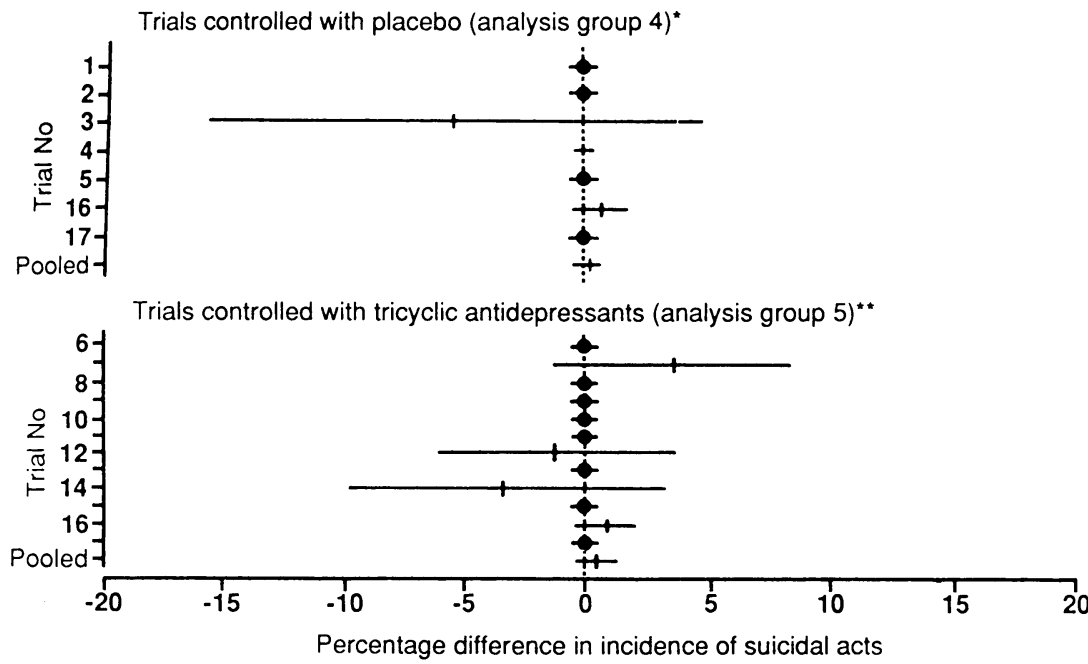

Trial No = as given in Appendix; $=$ observed incidence of 0 in both treatment groups -Breslow-Day $p=0.188$; adjusted incidence difference $0.2(-0.3$ to 0.7$), p=0.494$

"*Breslow-Day $p=0.163$; adjusted incidence difference $0.3(-0.4$ to $1 \cdot 1), p=0.419$.

FIG 1-Incidence differences and 95\% confidence intervals for suicidal acts in trials of fluoxetine controlled with placebo and tricyclic antidepressants

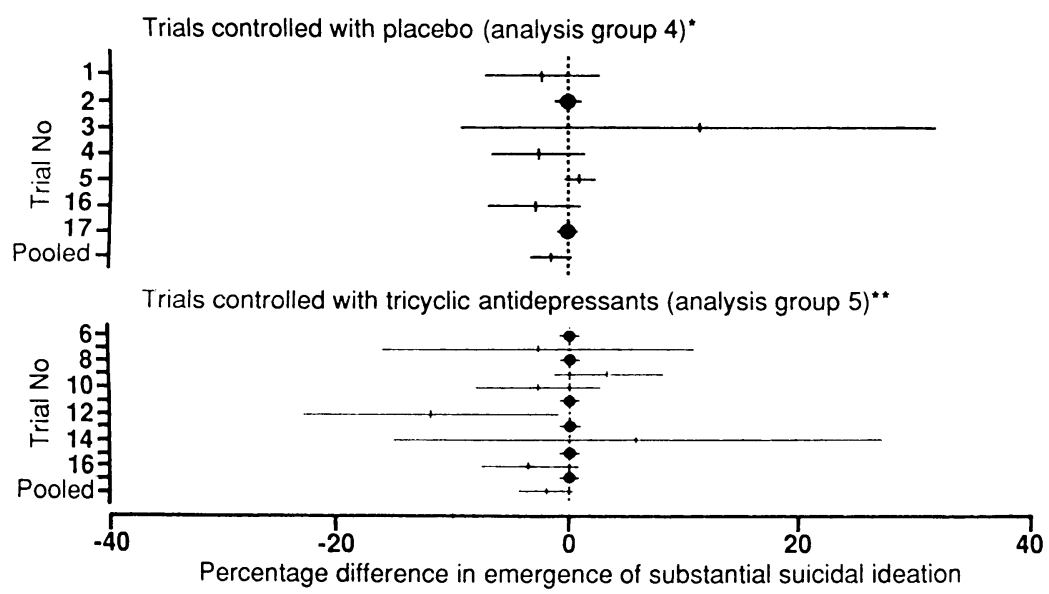

Trial No = as given in Appendix; - observed incidence of 0 in both treatment groups "Breslow-Day $\mathrm{p}=0.343$; adjusted incidence difference $-1.5(-3.3$ to 0.3$), p=0.094$

"Breslow-Day $p=0.124$; adjusted incidence difference $-1.8(-4.0$ to 0.4$), p=0.102$

FIG 2-Incidence differences and 95\% confidence intervals for emergence of substantial suicidal ideation in trials of fluoxetine controlled with placebo and tricyclic antidepressants with fluoxetine and tricyclic antidepressants $(2 \cdot 8(-2 \cdot 4$ to $8 \cdot 1), p=0 \cdot 294$ ).

The pooled incidence of improvement of suicidal ideation was $72 \cdot 2 \%$ for fluoxetine, $54 \cdot 8 \%$ for placebo, and $69 \cdot 8 \%$ for tricyclic antidepressants. Pearson's $\chi^{2}$ test showed significantly more improvement with fluoxetine than with placebo $(\mathrm{p}<0.001)$; fluoxetine and tricyclic antidepressants were not significantly different $(\mathrm{p}=0 \cdot 296)$.

\section{Discussion}

The occurrence of three suicidal acts during the brief placebo lead in period in a population screened to exclude serious suicidal risk emphasises the inherent danger of suicidality in major depressive disorder and its potential for emerging rapidly. The data analysed here, which were systematically collected in a blinded manner from a large total number of patients, do not show either increased risk of suicidal acts or the emergence of substantial suicidal ideation among patients treated with fluoxetine, relative to the risk with a tricyclic antidepressant or placebo. Suicidal acts were infrequent during double blind, controlled trials of fluoxetine lasting up to six weeks (fluoxetine $0.3 \%$, tricyclic antidepressants $0 \cdot 4 \%$, placebo $0 \cdot 2 \%$, and the pairwise comparisons by adjusted incidence differences within the pooled analysis groups did not show significant differences between fluoxetine and either placebo or tricyclic antidepressants. It must be kept in mind that if the $95 \%$ confidence interval around the adjusted incidence difference for a comparison of interest contains clinically important values (as defined by the reader) then these data may lack sufficient power due to insufficient sample size. However, for fluoxetine versus placebo this interval was $-0.3 \%$ to $0 \cdot 7 \%$, and for fluoxetine versus tricyclic antidepressants it was $-0 \cdot 4 \%$ to $1 \cdot 1 \%$.

Substantial suicidal ideation emerged marginally significantly less of ten with fluoxetine than with placebo $(\mathrm{p}=0.094$, Mantel-Haenszel adjusted incidence dif ference) and numerically less often with fluoxetine than with tricyclic antidepressants $(p=0 \cdot 102)$. Worsening to any degree at any time during treatmen did not differ with fluoxetine compared with placebo or tricyclic antidepressants. A significantly higher percentage of patients treated with fluoxetine experi enced improvement than did patients treated with placebo $(p<0.001)$; there was no significant difference in improvement between patients treated with fluoxetine and those treated with tricyclic antidepressants.

The results of the Pearson's $\chi^{2}$ analyses for the four outcome variables (suicidal acts, emergence of substantial suicidal ideation, worsening of suicidal ideation, and improvement of suicidal ideation) were consistent with the results obtained with the MantelHaenszel adjusted incidence difference analyses Therefore the $\chi^{2}$ analyses support the conclusions discussed above drawn from the incidence difference analyses.

The data reported here must be viewed in the context of epidemiological findings regarding depression and suicidality: $15 \%$ of patients with major depression will die by suicide, ${ }^{28} 20-40 \%$ will show suicidal behaviour, ${ }^{29}$ and up to $80 \%$ will experience suicidal ideation. ${ }^{30}$ Johnson $e t$ al, have reported that a community sample of persons meeting criteria for DSM-III major depressive disorder had a lifetime incidence of suicidal acts of $15 \cdot 4 \% \quad(7 \cdot 9 \%$ if noncomorbid and $19 \cdot 8 \%$ if major depression was accom panied by other diagnoses). ${ }^{31}$

Black et al reported that during a two year follow up of 1076 patients hospitalised for depression 25 suicides occurred $(0.0116$ suicide deaths per patient year not adjusted for deaths by other causes). ${ }^{+}$Fawcett et al

s




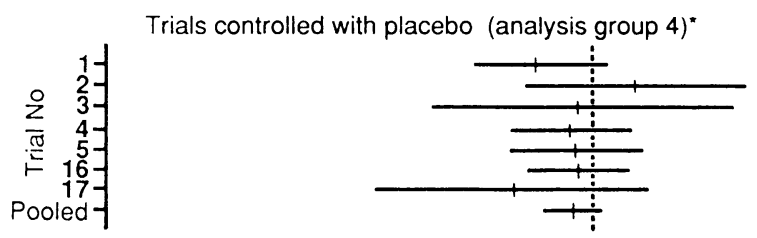

Trials controlled with tricyclic antidepressants (analysis group 5) ${ }^{\star \star}$

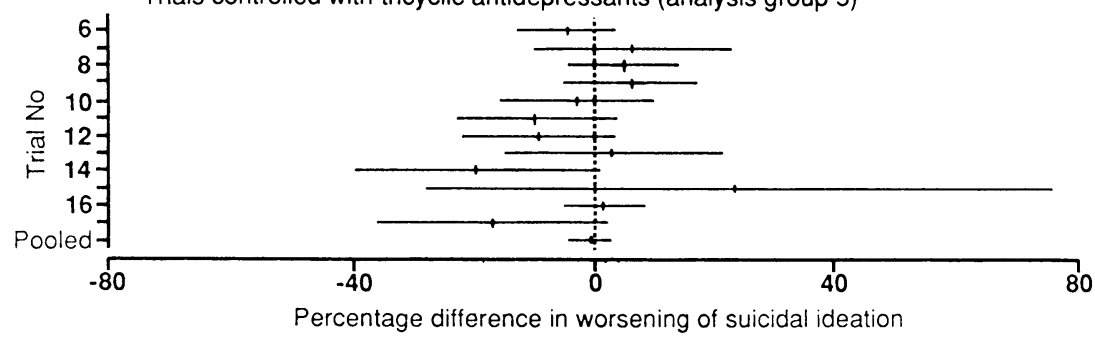

Trial No = as given in Appendix .

-Breslow-Day $p=0 \cdot 724$; adjusted incidence difference $-2 \cdot 6(-6 \cdot 6$ to $1 \cdot 3), p=0 \cdot 196$

*Breslow-Day $p=0.173$; adjusted incidence difference $-0.5(-4.2$ to 3.2$), p=0.793$

FIG 3-Incidence differences and $95 \%$ confidence intervals for worsening of suicidal ideation from baseline to highest score in trials of fluoxetine controlled with placebo and tricyclic antidepressants
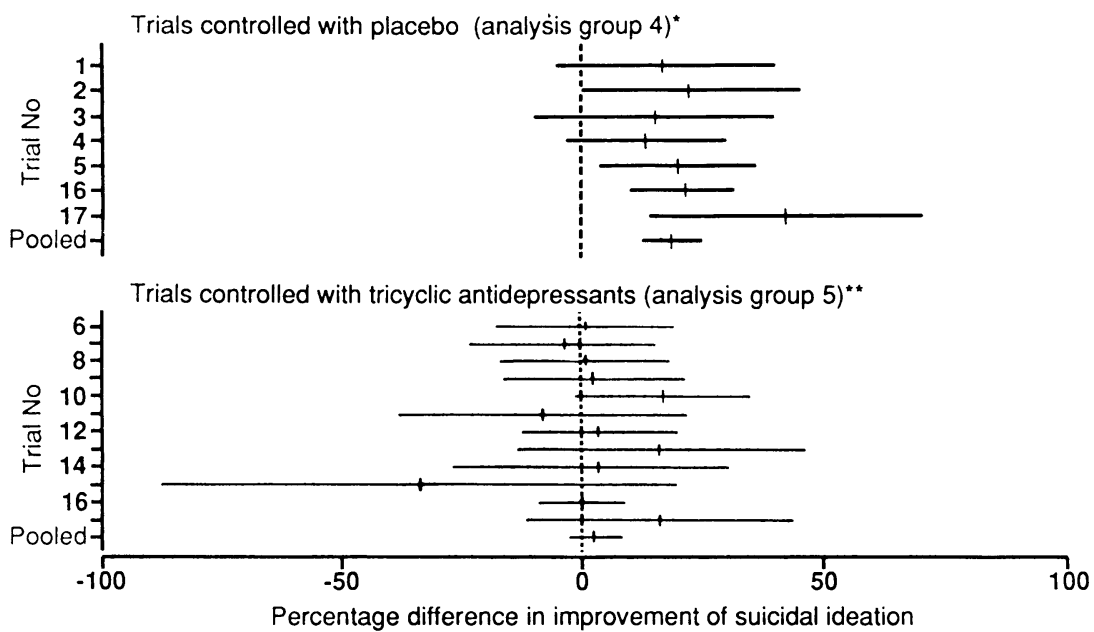

Trial No = as given in Appendix .

-Breslow-Day $p=0.805$; adjusted incidence difference 18.8(12.7 to 24.9), $p<0.001$

* Breslow-Day $\mathrm{p}=0.755$; adjusted incidence difference $2.8(-2.4$ to 8.1$), p=0.294$.

FIG 4-Incidence differences and $95 \%$ confidence intervals for improvement of suicidal ideation from baseline to endpoint in trials of fluoxetine controlled with placebo and tricyclic antidepressants

reported that during a 10 year follow up of 954 depressed patients, 68 suicides occurred $(0.0071$ suicide deaths per patient year, not adjusted for deaths by other causes). ${ }^{32}$ The number of attempts per completed suicide has been variously estimated between eight and 33 , with a reasonable estimate being 10 attempts for each fatal suicide. ${ }^{334}$ Therefore, rates of non-fatal suicidal acts in the cohorts reported by Black $e t$ al and Fawcett $e t$ al might be estimated to be 0.116 and 0.071 per patient year, respectively.

Muijen et al have reported a significantly greater reduction in suicidal ideation with fluoxetine treatment than with comparators. ${ }^{14}$ Sacchetti et al have reported that patients with a history of suicidal acts have a higher rate of response (percentage of patients with a $50 \%$ or greater reduction in Hamilton depression rating scale score) to fluoxetine and clomipramine than those without a history of such acts and that suicidal patients also show a higher rate of response to these serotonin uptake inhibitors than to nortriptyline and desipramine. ${ }^{16}$ Montgomery and Pinder ${ }^{13}$ and Wakelin ${ }^{15}$ have described studies suggesting that other serotonin uptake inhibitors may also result in significantly better improvement in suicidal ideation. The rate of emergence of suicidal ideation during treatment with fluoxetine presented here is less than half the $3.5 \%$ rate suggested in other reports. ${ }^{612}$ The significant $(\mathrm{p}<0.001)$ superiority of fluoxetine compared with placebo with respect to improvement of suicidal ideation and the marginally significant $(\mathrm{p}=0.094$, Mantel-Haenszel adjusted incidence difference; $p=0.042$, Pearson's $\chi^{2}$ test) superiority of fluoxetine compared with placebo with respect to emergence of substantial suicidal ideation suggest a potentially beneficial effect for fluoxetine with regard specifically to suicidality. This is consistent with the findings of Muijen et al for fluoxetine, as well as with those described by Montgomery and Pinder and Wakelin for other serotonin uptake inhibitors. ${ }^{13-15}$

Though the sample size analysed here was large, the possibility cannot be excluded that some extremely rare phenomenon was not detected. Although item 3 on the Hamilton depression rating scale failed to detect significant differences among the treatment groups with respect to operationally defined emergence of substantial suicidal ideation (baseline score of 0 or 1 increasing to 3 or 4 at any time during treatment), it may not detect important changes in rare, individual patients such as those described by Damluji and Ferguson, Teicher $e t a l$, and others. ${ }^{5-79}{ }^{10} \mathrm{It}$ is possible that among the $1 \cdot 2 \%$ of fluoxetine treated, $3 \cdot 6 \%$ of tricyclic treated, and $2 \cdot 6 \%$ of placebo treated patients who experienced the emergence of substantial suicidal ideation there might have been smaller subsets with some very unusual change that differed among the treatments. What these data show is in fact a lack of increased risk with fluoxetine in these clinical trials of up to six weeks' duration. The results obtained here may not be generalisable to a population with different clinical characteristics (patients more seriously suicidal at start of treatment) who have been treated for a longer period.

There is no dispute that both suicidal ideation and suicidal acts are inherent risks associated with depression in general. Therefore, when starting or continuing treatment of any kind with depressed patients clinicians must always remain vigilant for the emergence of suicidal ideation or change in its severity so that appropriate action can be taken.

We thank the following individuals for their review of the data presented here: Dr Jan Fawcett, Rush Medical College and Presbyterian St Luke's Medical Center, Chicago; Dr Jerrold F Rosenbaum, Massachusetts General Hospital, Boston; Gary D Tollefson, St Paul-Ramsey Medical Centre, Minnesota; Dr George Winokur, University of Iowa College of Medicine Psychiatric Hospital, Iowa City; Professor G W Ashcroft, Aberdeen Royal Infirmary, Aberdeen; Professor C L E Katona, University College and Middlesex School of Medicine, London: Professor $\mathrm{H}$ Moeller, Neurologic and Psychiatric University Clinic, Bonn; Professor B MuellerOrlinghausen, Berlin.

1 Buda $M$, Tsuang MT. The epidemiology of suicide: implications for clinical practice. In: Blumenthal SJ, Kupfer DJ, eds. Suicide over the life cycle: risk factors, assessment, and treatment of suicidal patients. Washington, DC American Psychiatric Press, 1990:17-37.

2 Black DW, Winokur G. Suicide and psychiatric diagnosis. In: Blumenthal SJ Kupfer DJ, eds. Suicide over the life cycle: risk factors, assessment, and treatment of suicidal patients. Washington, DC: American Psychiatric Press, 1990:135-53.

3 Hirschfeld RMA, Davidson L. Risk factors for suicide. In: Frances AJ, Hale RE, eds. Psychiatry update: American psychiatric association annual review, Vol. 7. Washington, DC: American Psychiatric Press, 1988:307-33.

4 Black DW" Winokur G, Mohandoss E, Woolson RF, Nasrallah A. Does treatment influence mortality in depressives? A follow-up of 1076 patients with major affective disorders. Ann Clin Psychiatry 1989;1:165-73.

5 Damluii NF, Ferguson JM. Paradoxical worsening of depressive symptomatology caused by antidepressants. F Clin Psychopharmacol 1988:8:347-9.

6 Teicher $\mathrm{MH}$, Glod $\mathrm{C}$, Cole JO. Emergence of intense suicidal preoccupation during fluoxetine treatment. Am f P Pychiatry 1990;147:207-10.

7 Dasgupta $\mathrm{K}$. Additional cases of suicidal ideation associated with fluoxetine.

Am f Psychiatry 1990;147:1570.
8 Hoover CE. Additional cases of suicidal ideation associated with fluoxetine. Am f P Pychiatry 1990;147:1570-1.

9 Masand P. Gupta S, Dewan M. Suicidal ideation related to fluoxetine treatment. N Engl f Med 1991;324:420

10 King RA, Riddle MA, Chappell PB, Hardin MT, Anderson GM, Lombroso P. et al. Emergence of self-destructive phenomena in children and adolescents during fluoxetine treatment. I Am Acad Child Adolesc Psychiatry 1991;30 179-86. 
$11 \mathrm{How} e \mathrm{CE}$. Suicidal ideation not associated with fluoxetine. A $m$ f Psychiatry 1991:148:543.

12 Hava $M$, Rosenbaum J. Suicidality and fluoxetine: is there a relationship? fClin Pswchiatry 1991;52:108-11.

13 Montgomery SA, Pinder RM. Do some antidepressants promote suicide? P'suchopharmacologv 1987;92:265-6.

14 Muijen M, Roy D, Silverstone T, Mehmet A, Christic M. A comparative clinical trial of fluoxetine, mianserin and placebo in depressed outpatients. Acta Psychiatr Scand 1988;78:384-90

15 Wakelin JS. The role of serotonin in depression and suicide: do serotonin reuptake inhibitors provide a key? Adzances in Biological Psychiatry 1988:17:70-83.

16 Sacchetti E, Vita A, Guarneri L, Cornacchia M. The effectiveness of fluoxetine, clomipramine, nortriptyline and desipramine in major depressives with suicidal behaviour: preliminary findings. In: Cassano GB, Akiskal HS, eds. Serotomin-related psychiatric syndromes: clinical and therapeutic links. London: Roval Society of Medicine, 1991. International congress and stmposium series No. 165 .

17 Rouillon F, Phillips R, Serrurier D, Ansart E Gérard MJ. Rechutes de dépression unipolaire et efficacité de la maprotiline. L'Encéphale 1989;15: $527-34$

18 Hamilton $\mathrm{M}$. Development of a rating scale for primary depressive illness. $\mathrm{Br} f$

19 Talbott MW Hadley PA Lister WC, Rader M, Hizer RE, Pettinga CW, et al. Adverse drug events: global collection, analysis, and reporting. Fournal of Clinical Research and Drug Decelopment 1987;1:53-73.

20 Spitzer RL, Endicott J, Robins E. Research diagnostic criteria (RDC) for a selected group of functional disorders, 3rd ed. updated. New York: NY State Psychiatric Institute, Biometrics Research, 1984.

21 American Psychiatric Association. Diagnostic and statistical manual of mental disorders, 3rd ed. Washington, DC: APA, 1980.
22 Fleiss JI. Statistical methods for rates and proportions, 2nd ed. New York: Wiley, 1981:61-7, 173-6.

23 Greenland S. Robins JM. Estimation of a common effect parameter from sparse follow-up data. Biometrics 1985;41:55-68.

24 Sato $T$. Confidence intervals for effect parameters common in cancer epidemiology. Environ Health Perspect 1990;37:95-101.

25 StatXact user manual. Cambridge, Massachusetts: Cytel Software Corporation, 1989

26 Kleinbaum DG, Kupper I.I, Morgenstern H. Epidemiological research: principles and quantitative methods. New York: Van Nostrand Reinhold, 1982.

27 SAS user's guide, statistics, version 5 edition. Cary, North Carolina: SAS Institute, 1985.

28 Guze SB, Robins E. Suicide and primary affective disorders. Br $\mathcal{F}$ Psychiatry 1970;117:437-8

29 Brent DA, Kupfer DJ, Bromet EJ, Dew MA. The assessment and treatment of patients at risk for suicide. In: Frances AJ, Hales RE, eds. Psychiatry update: American Psychiatric Association annual review. Vol 7. Washington, DC: American Psychiatric Press, 1988:353-85.

30 Roose SP, Glassman AH. Delusional depression. In: Georgotas A, Cancro R, eds. Depression and mania. New York: Elsevier, 1988:76-85.

31 Johnson J, Weissman MM, Klerman GL. Panic disorder, comorbidity and suicide attempts. Arch Gen Psychiatry 1990;47:805-8.

32 Fawcett J, Scheftner WA, Fogg L, Clark DC, Young MA, Hedeker D, et al. Time-related predictors of suicide in major affective disorder. $A m \mathcal{J}$ Pychiatry 1990:147:1189-94.

33 Paykel ES, Myers JK, Lindenthal JJ, Tanner J. Suicidal feelings in the general population: a prevalence study. Br f Psychiatry 1974;124:460-9.

34 Murphy GE. Prevention of suicide. In: Frances AJ, Hales RE, eds. Psychiatry update: American Psychiatric Association annual review. Vol 7. Washington, DC: American Psychiatric Press, 1988:403-21.

\section{Appendix}

TABLE AI - Double blind clinical trials of fluoxetine versus placebo in depression

\begin{tabular}{|c|c|c|c|c|c|}
\hline Trial No (reference No) & $1(1,2)$ & 2 Unpublished & $3(3)$ & $4(4-8)$ & $5(9)$ \\
\hline Investigator (city, state or province) & $\begin{array}{l}\text { Fabre (Houston, Austin, TX) } \\
\text { Finnerty, Goldberg (Boston, } \\
\text { MA) } \\
\text { Rickels, Case (Philadelphia, } \\
\text { PA) }\end{array}$ & Cohn (Long Beach, CA $)$ & Simeon (Ottawa, $\mathrm{ON}$ ) & $\begin{array}{l}\text { Branconnier (Brookline, MA) } \\
\text { Cohn (Long Beach, CA) } \\
\text { Crimson (Austin, TX) } \\
\text { Dunner (Seattle, WA) } \\
\text { Fabre (Houston, TX) } \\
\text { Feighner (Encinitas, CA) } \\
\text { Fieve (New York, NY) } \\
\text { Mendels (Philadelphia, PA) } \\
\text { Shrivastava (New York, NY) } \\
\text { Smith (Portland, OR) }\end{array}$ & $\begin{array}{l}\text { Chouinard (Montreal, PQ) } \\
\text { Cohn (Long Beach, CA) } \\
\text { Dessain (Brookline, MA) } \\
\text { Fabre (Houston, TX) } \\
\text { Feighner (Encinitas, CA) } \\
\text { Fieve (New York, NY) } \\
\text { Grosser (Salt Lake City, UT) } \\
\text { Mendels (Philadelphia, PA) } \\
\text { Nysewander (Tuker, GA) } \\
\text { Woerner (Springfield, IL) }\end{array}$ \\
\hline Total No of patients & 111 & 90 & 40 & 746 & 363 \\
\hline $\begin{array}{l}\text { Frequency of visits during double blind } \\
\text { phase }\end{array}$ & Weekly & $\begin{array}{l}2 / \text { Wk week } 1,3 / \text { wk week } 2, \\
\text { remainder weekly }\end{array}$ & Weekly & Weekly & Weekly \\
\hline Weeks of double blind treatment & 5 & 6 & 6 & 6 & 6 \\
\hline Placebo lead in (length) & Yes (one week) & Yes (one week) & Yes (one week) & Yes (one week) & Yes (one week) \\
\hline Placebo response exclusion criteria & $\begin{array}{l}\text { HAMD } \geqslant 20 \% \text { decrease or } \\
\text { HAMD }<20\end{array}$ & $\begin{array}{c}\text { HAMD } \geqslant 20^{\circ} \% \text { decrease or } \\
\text { HAMD }<20\end{array}$ & $\begin{array}{c}\text { HAMD } \geqslant 20 \% \text { decrease or } \\
\text { HAMD }<20\end{array}$ & $\begin{array}{c}\text { HAMD } \geqslant 20 \% \text { decrease or } \\
\text { HAMD }<20 ; \text { or HAMD } \\
\geqslant 20 \% \text { decrease or HAMD } \\
<14\end{array}$ & $\begin{array}{c}\text { HAMD } \geqslant 20 \% \text { decrease or } \\
\text { HAMD }<20\end{array}$ \\
\hline Diagnostic system & $\mathrm{RDC}$ & DSM-HII & DSM-III & DSM-III & DSM-III \\
\hline Diagnostic criteria & MDD & MDD & MDD & MDD & MDD \\
\hline Inpatient or outpatient & Outpatient & Outpatient & Inpatient or Outpatient & Outpatient & Outpatient \\
\hline Serious suicidal risk exclusionary & Yes & Yes & Yes & Yes & Yes \\
\hline Start and finish (month/year) & $9 / 79$ to $1 / 82$ & $11 / 83$ to $5 / 86$ & $4 / 84$ to $3 / 88$ & $1 / 84$ to $3 / 85$ & $9 / 84$ to $3 / 86$ \\
\hline Median (range) age (years) & $39(18-67)$ & $41(22-62)$ & $16(12-17)$ & $37(18-70)$ & $38(18-65)$ \\
\hline$\%$ Women & 69 & 50 & 55 & 58 & 61 \\
\hline$\%$ White & 90 & 92 & 100 & 89 & 90 \\
\hline \multicolumn{6}{|l|}{ Fluoxetine: } \\
\hline No of patients & 55 & 45 & 21 & 639 & 285 \\
\hline Median (range) days treated & $60(20-80$ & $60(20-80)$ & $30(10-30)$ & 20,40 , or 60 fixed & 5,20 , or 40 fixed \\
\hline Baseline HAMD score: & $31(1-43$ & $35(2-47)$ & $41(5.49)$ & $41(1-60)$ & $42(1-56)$ \\
\hline Mean (range) 21 items & $27 \cdot 1(21-40)$ & $25 \cdot 0(20-31)$ & $24 \cdot 6(19-34)$ & $20 \cdot 6(14-35)$ & $25 \cdot 3(14-40)$ \\
\hline $\begin{array}{l}\text { Mean range item } 3 \\
\text { No of suicidal acts }\end{array}$ & $0 \cdot 9(0-3)$ & $0 \cdot 9(0-2)$ & $1 \cdot 8(0-3)$ & $0 \cdot 7(0-4)$ & $0.9(0-3)$ \\
\hline \multirow{3}{*}{$\begin{array}{l}\text { No of patients with score } 0 \text { or } 1 \text { at } \\
\text { baseline and } \geqslant 1 \text { double blind score } \\
\text { No of patients with emergence of } \\
\text { substantial suicidal ideation }\end{array}$} & & & & 1 & \\
\hline & 39 & 39 & 9 & 493 & 210 \\
\hline & & & 1 & 4 & 2 \\
\hline \multicolumn{6}{|l|}{ Placebo: } \\
\hline $\begin{array}{l}\text { No of patients } \\
\text { Median (range) days treated }\end{array}$ & $\begin{array}{c}56 \\
34(4-40)\end{array}$ & $35 \stackrel{45}{2-40)}$ & $\begin{array}{c}19 \\
42(23-49)\end{array}$ & $\begin{array}{c}107 \\
42(5-60)\end{array}$ & $\begin{array}{c}78 \\
40(1-48)\end{array}$ \\
\hline $\begin{array}{l}\text { Baseline HAMD score: } \\
\text { Mean (range) } 21 \text { items } \\
\text { Mean (range) item } 3\end{array}$ & $\begin{array}{c}27 \cdot 1(20-42) \\
1 \cdot 0(0-3)\end{array}$ & $\begin{array}{c}24 \cdot 1(20-30) \\
1 \cdot 0(0-2)\end{array}$ & $\begin{array}{c}24 \cdot 6(16-35) \\
1 \cdot 8(0-3)\end{array}$ & $\begin{array}{c}20 \cdot 7(14-37) \\
0 \cdot 7(0-3)\end{array}$ & $\begin{array}{l}25 \cdot 8(20-42) \\
1 \cdot 0(0-3)\end{array}$ \\
\hline No of suicidal acts & & & 1 & & \\
\hline $\begin{array}{l}\text { No of patients with score } 0 \text { or } 1 \text { at } \\
\text { baseline and } \geqslant 1 \text { double blind score } \\
\text { No of patients with emergence of }\end{array}$ & 41 & 37 & 8 & 87 & 53 \\
\hline $\begin{array}{l}\text { sobstantial suicidal ideation } \\
\text { substat }\end{array}$ & 1 & & & 3 & \\
\hline
\end{tabular}

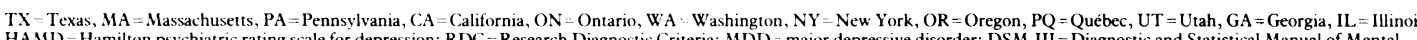
HAMI $=$ Hamilton ps,
Disorders, 3rd edition.

1 Fabre IF, Crismon L. Efficacy of fluoxetine in outpatients with major depression. Current Therapeutic Research 1985;37:115-23.

2 Rickels K, Amsterdam JD, Avallone MF. Fluoxetine in major depression: a controlled study. Current Therapeutic Research 1986;39:559-63.

3 Simeon JG, Dinicola VF, Ferguson HB, Copping W. Adolescent depression: a placebo-controlled fluoxetine treatment study and follow-up. Prog Neuropsychopharmacol Biol Psychiatry 1990;14:791-5.

4 Wernicke JF, Dunlop SR, Dornseif BE, Zerbe RL. Fixed-dose fluoxetine therapy for depression. Psychopharmacol Bull 1987;23:164-8.
5 Fabre IF, Putman HP III. A fixed-dose clinical trial of fluoxetine in outpatients with major depression. $\mathcal{F}$ Clin Psychiatry 1987;48:406-8.

6 Dunlop SR, Dornseif BE, Wernicke JF, Potvin JH. Pattern analysis shows beneficial effects of fluoxetine treatment in mild depression. I'sychopharmacol Bull 1990;26:173-80.

7 Fieve RR, Goodnick PJ, Peselow ED, Barouche F, Schlegel A. Pattern analysis of antidepressant response to fluoxetine. $\mathcal{F}$ Clin Psychiatry 1986;47:

8 Goodnick PJ, Fieve RR, Peselow ED, Barouche F, Schlegel A. Double-blind 


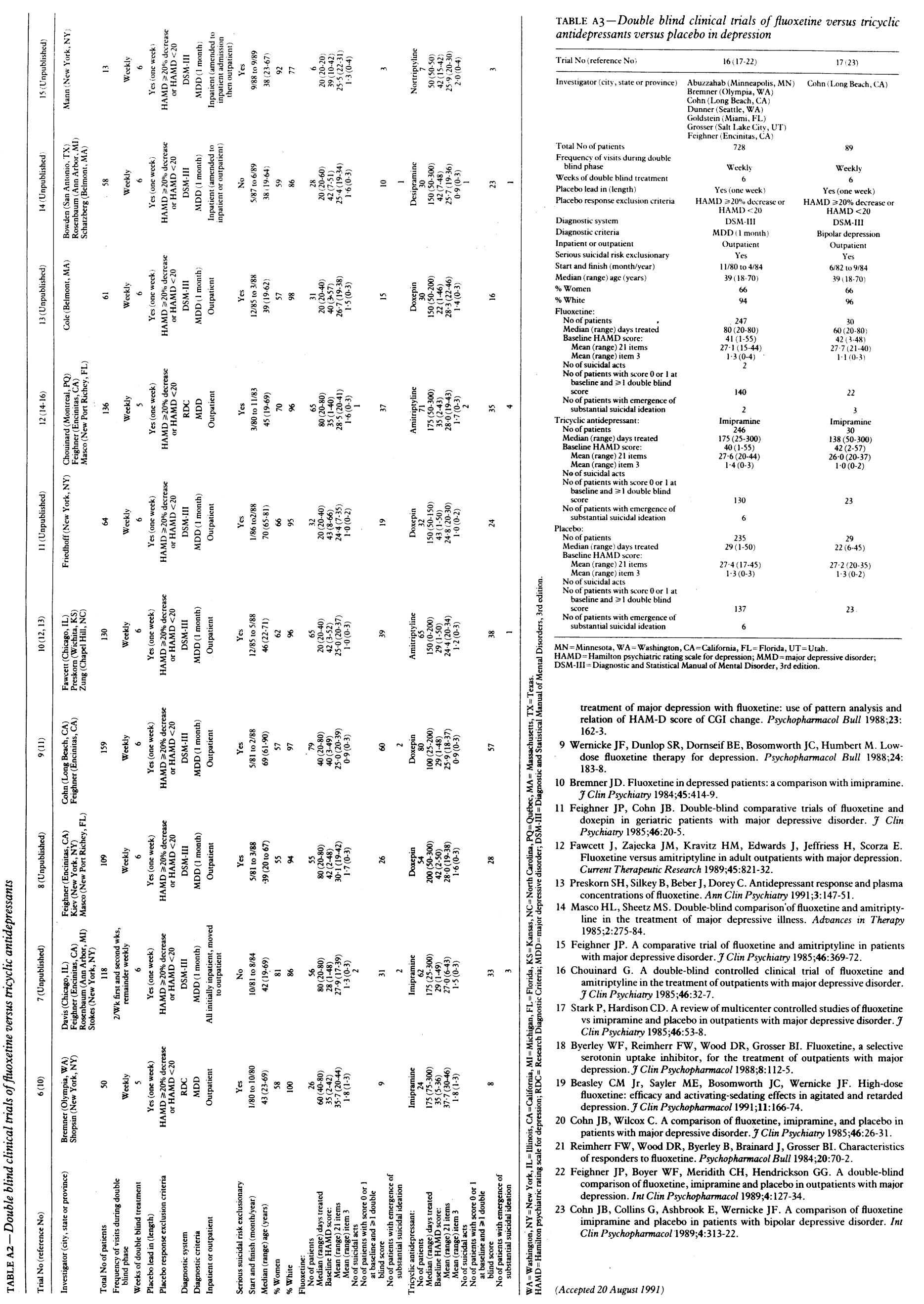

